\title{
Menjadi Pemimpin Musik Gereja Yang Handal
}

\author{
Jonathan Tanujaya
}

\begin{abstract}
Abstrak
Beberapa tahun terakhir ini, pertumbuhan jemaat gereja-gereja ( khususnya gereja Injili ) semakin hari semakin lambat dan bahkan merasa tidak dapat bertumbuh baik secara kuantitas maupun kualitas. Sehingga pemimpin-peminpin gereja mulai mencari penyebab dari lambatnya pertumbuhan jemaat mereka. Disaat yang bersamaan, ada gereja-gereja yang tibatiba bertumbuh dengan pesat dalam jumlah jemaat yang banyak dalam kurun waktu yang singkat. Sehingga banyak gereja lainnya ingin meniru dan belajar dari gereja tersebut, salah satunya yaitu melalui corak-corak ibadah khusus didalam musik dan lagunya.

Apa yang terjadi didalam ibadah mereka? Ternyata mereka beribadah dengan puji-pujian yang diiringi dengan alat-alat musik ( guitar elektrik, keyboard, drum set dan bass ). Sehingga membangkitkan suasana dan semangat ibadah mereka. Hal ini sangat menarik perhatian pemuda dan pemudi gereja-gereja yang masih bersifat konservatif ( Injili ). Sehingga mulai meniru dan menghilangkan tata ibadah tradisi yang ada. Apa kah ini benar dan pasti berhasil? Penulis tidak menyangkal dan menolak cara ibadah mereka, tetapi penulis ingin bertanya kepada Hamba Tuhan, majelis, penatua serta tim ibadah yang ada saat ini, apakah kita sudah memiliki Pemimpin Musik Gereja yang Handal yang benar-benar mengerti musik gerejawi yang dapat membangun kerohanian jemaat. Dan membimbing pelayan-pelayan musik dalam ibadah dengan baik dan benar. Penulis menulis tema ini karena penulis sejak kecil sudah dipimpin dan dibina oleh pembimbing kami dengan belajar musik gereja yang baik dan benar, mengerti setiap lagu yang dinyanyikan bahkan menceritakan tokoh-tokoh penulis lagu tersebut. Berharap tulisan ini dapat dipelajari oleh pemimpin-peminpin gereja baik pendeta ( Hamba Tuhan), majelis, penatua maupun tim musik ibadah. Sehingga kita dapat menbina dan mendidik jemaat dengan musik gereja yang benar melalui seorang Pemimpin Musik Gereja yang handal.
\end{abstract}

\section{Pendahuluan}

Gereja yang tidak bernyanyi bukanlah gereja- karl Barth. Mencari pemimpin musik gereja yang handal bukan berarti pemimpin yang sempurna. Pemimpin yang berdasarkan apa? Pemimpin gereja saat ini telah kehilangan pandangan tentang teologi beribadah, sehingga lebih banyak meniru dari pada belajar, menghindari kesulitan dari pada memperbaiki sistim, lebih suka revolusi dari pada reformasi. Banyak gereja fokus pada penginjilan sehingga memiliki Hamba Tuhan yang handal didalam penginjilan, fokus pada pemuda atau remaja sehingga memiliki Hamba Tuhan yang handal didalam pembinaan pemuda dan remaja, focus pada Sekolah Minggu sehingga mencari Hamba Tuhan yang spesialis Sekolah Minggu. Tetapi satu hal yang sangat menyedihkan yaitu gereja jarang sekali bahkan ada yang tidak memiliki seorang Pembina/pemimpin Musik Gereja yang handal. Sehingga pelayanan musik gereja dilakukan sesuai dengan cara meniru dan selera masing-masing gereja. Padahal setiap Hamba Tuhan maupun majelis ingin ibadahnya bagus, pimpinan pujian handal, lagu-lagu nya berkualitas, pemain musik bagus. Tetapi tidak ada pemimpinnya. Maka penulis melalui tulisan ini ingin membahas bagaimana pandangan alkitab tentang seorang Pemimpin Musik Gereja yang handal. Agar semua gereja dapat peduli dikemudian hari. 


\section{Isi}

\section{Pemimpin Gereja}

Banyak jenis pelayanan di setiap gereja, tetapi pelayanan musik gereja adalah bagian yang tak terpisahkan dan bagian yang agak berbeda dengan pelayanan lain. Dengan perkembangan dan perubahan zaman, salah satu yang paling gampang berubah yaitu musik termasuk musik gereja. Dan oleh sebab itu, pelayanan musik gereja mengalami tantangan dan pergumulan yang cukup berat dari gereja serta mengalami kesulitan yang besar didalam gereja, maka itu gereja saat ini harus memperhatikan beberapa hal tentang Pelayan Musik Gereja, Pelayanan Musik Gereja dimulai dari:

1. Para Hamba Tuhan/Gembala

Hamba Tuhan atau pendeta adalah pemimpin rohani yang tertinggi didalam sebuah gereja. Mereka bertanggung jawab kepada seluruh aktivitas gereja yang berhubungan dengan pertumbumbuhan rohani jemaat termasuk melalui pujian-pijian rohani. Gereja Methodist memiliki Buku Pujian Rohani tersendiri. Dengan kata lain, kepedulian Musik Gereja harus dimulai dari Hamba Tuhan atau Gembala. Jauh lebih bagus jikalau para pendeta dan Hamba Tuhan mengerti musik gereja khususnya lagu-lagu Hymne ( GMI memilikinya ).

2. Para Majelis Gereja/penatua.

Majelis gereja maupun penatua gereja membantu Pendeta maupun Hamba Tuhan dalam bidang masing-masing demi tercapainya visi dan misi gereja, salah satunya dalam bidang musik gerejawi. Majelis gereja bidang musik gereja mestinya mengerti makna dan tujuan dari musik gereja didalam pertumbuhan kerohanian jemaatnya.

3. Para Pelayan Musik Gereja.

Mereka termasuk Pemimpin Musik Gereja ( Music Director), pianis, liturgis, pemimpin paduan suara. Mereka semua didalam sebuah komisi/departemen yang disebut Komisi Musik Gereja yang akan dipimpin oleh seorang majelis dan dibina oleh seorang Pemimpin Musik Gereja ( Music Director ). Pemimpin Musik Gereja tersebut akan mengkordinasi dengan semua pelayanan musik gereja. Dia akan mengadakan pembinaan, pengajaran, rekrutmen dan pelatihan.

\section{Pemimpin Musik Gereja.}

Pemimpin Musik Gereja yang dimaksud disini adalah seorang Music Director yang mengerti dan pernah belajar musik gereja dengan baik emerta memiliki latar belakang musik gereja yang handal. Jikalau pemimpin musik gereja dipegang oleh pemimpin yg berlatar belakang musik pop, maka dia akan memasukan musik pop ke dalam gereja juga. maka cirri-ciri Pemimpin Musik Gereja yang handal adalah pemimpin yang sesuai dengan ajaran Firman Tuhan didalam 1 Tawarik 25:1-7.

a. Pemimpin yang mengerti dan menguasai musik.

Dalam perikop ini, Daud lah yang memulai mencari, membina dan melatih anggotanya walaupun Bait Suci Allah tidak boleh dibangun olehnya. Tetapi dengan sikap rendah hati dan kasih kepada Tuhan serta kerinduan akan Bait Suci Allah, maka Raja Daud memakai karunia nya didalam musik gereja ( karena banyak membuat Mazmur ) menjadi seorang pemimpin Musik yang handal.

Gereja saat ini harus memiliki seorang Pemimpin Musik Gereja yang seperti Raja Daud. Bukan sembarangan orang bisa memimpin dan menjalani bidang ini. Kelemahan gereja saat ini adalah hanya mempersiapkan Hamba Tuhan membuka Pos PI tetapi tidak mempersiapkan hamba Tuhan atau Pemimpin Musik Gereja. Dan banyak gereja besar tidak memiliki Pemimpin Musik Gereja sampai saat ini. seolaholeh ini tidak penting. 
b. Pemimpin yang memilih dan merekrut

Dalam perikop ini, Raja Daud bersama-sama dengan panglimanya memilih Asaf, Heman serta Yedutun. Mereka bertiga adalah ahli seni ( 7 ). Raja Daud tidak sembarangan memilih orang, tetapi memilih orang-orang yang bertalenta didalam musik dengan tujuan mempersiapkan mereka untuk ibadah. Disamping itu, mereka bertiga dapat melatih dan mengajar musik kepada anak-anak mereka. Gereja masa kini harus memperhatikan hal ini dan memiliki pelayan-pelayan musik tersebut. Raja Daud mempersiapkan mereka jauh-jauh hari sebelum Bait Suci dibangun. Gereja harus mempersiapkan orang yang bertalenta musik mulai saat ini. 4 tahun kemudian akan memiliki seorang Pemimpin Musik Gereja yang handal.

Penulis menghimbau, Jangan terlamtat! Mari bergabung dengan STTWMI di Fakultas Musik Gerejawi, penulis adalah salah satu dosen disana. Kami memiliki fasilitas, sarana dan prasarana bagi siswa-siswi musik gereja. Kami memiliki dosen-dosen dari Singapore, Korea Selatan yang sudah pengalaman dan terdidik.

c. Pemimpin yang dapat melatih dan membina.

Dalam perikop ini menjelaskan bahwa baik Asaf, Heman maupun Yedutun melatih dan membina anak-anak mereka dengan berbagai jenis alat musik dan nyanyian. Raja Daud sangat peduli kepada KUALITAS sebuah musik. Sikap ini yang perlu gereja perhatikan. Gereja banyak menghabiskan dana untuk misi dan pembinaan lainnya, tetapi gereja harus peduli pada pembinaan musik gereja. Tentu jauh lebih baik jikalau gereja sudah memiliki Pemimpin Musik Gereja sebagai Musik Directornya.

\section{Peran Pemimpin Musik Gereja.}

Sebagai Pemimpin Musik Gereja, dia harus mengetahui tugas dan tanggung jawabnya dalam pelayanan musik gerejawi. Jenis lagu apa yang harus dipelajari dan dinyanyikan demi pertumbuhan kerohanian jemaat? Tata Ibadah yang bagaimana layak dilakukan ? Bagaimana cara mengiringi pujian rohani yang benar? Semuanya adalah tugas dan tanggung jawab seorang Pemimpin Musik Gereja. Dalam Jounal ini, penulis ingin membahas jenis lagu yang disebut HYMNE yang sudah bermanfaat pada gereja baik masa lalu maupun sekarang. Tetapi sangat disayangkan, banyak gereja sudah mengabaikan bahkan lupa lagu hymne. Mungkin gereja tidak memiliki Pemimpin Musik Gereja yang mengerti hymne atau gereja tidak mau menyanyikannya lagi ( karena dianggap sudah kuno ). Pada hal hymne memiliki peran yang sangat bermanfaat bagi pertumbuhan rohani jemaat, karena:

a) Hymne dapat menolong gereja menggembalakan jemaat.

Pemimpin gereja ( Hamba Tuhan/majelis ) memiliki kewajiban menggembalakan rohani jemaat baik melalui Firman Tuhan maupun lagu rohani. Tetapi lagu rohani yang bagaimana dapat menggembalakan rohani jemaat?

Ronald Allen berpendapat bahwa Hymne adalah salah satu cara terbaik untuk mengajar kebenaran kepada umat Tuhan karena didalam ada Firman Tuhan. Disaaat umat Tuhan tidak dapat bergereja ( sakit maupun penganiayaan ), maka lagu hymne lah yang dapat menguatkan iman mereka.

b) Hymne dapat menolong gereja mengajarkan kebenaran.

Hymne memang bukan alkitab. Tetapi hymne ditulis oleh hamba-hamba Tuhan yang memiliki latar belakang iman yang baik. Salah satu lagu "A Mighty Fortress Is Our God" yang ditulis oleh Martin Luther diambil dari Mazmur 46. Kata-katanya mengajarkan bahwa hanya Tuhan adalah benteng hidup kita dan didalam Tuhan Yesus Kristus sebagai Juru Selamat kita yang menjamin kehidupan kita. Puji Tuhan! 
Saat ini STTWMI mempunyai Fakultas Musik Gereja didalamnya mengajarkan mata pelajaran Hymnologi. Mata pelajaran ini sangat membantu mahasiswa mengerti lagu-lagu hymne. Khususnya lagu hymne Methodist.

c) Hymne dapat menolong gereja didalam penyembahan.

Sebuah kesalahan besar saat ini dimana gereja menganggap hymne tidak layak lagi didalam penyembahan sehingga banyak gereja menggantikan hymne dengan lagulagu lain. Padahal lagu humne lah yang paling banyak kategori penyembahan ( ibadah ). Seperti Rejoice, The Lord is King ditulis oleh Charles Wesley yang diambil dari Kitab Filipi 4:4 dengan bait pertama menjelaskan Tuhan sebagai Raja yang patut disembah dan bait kedua dan ketiga menjelaskan Tuhan Yesus memiliki kasih serta Dia akan bertahta selamanya. Fanny J. Crosby menulis lagu "To God Be the Glory" dengan bait pertama menceritakan kasih Allah Bapa, bait kedua menceritakan Penebusan oleh darah Tuhan Yesus Kristus dan bait ke tiga menceritakan harapan didalam Tuhan yesus Kristus. Martin Luther berkata: Jikalau seseorang tidak suka hymne, dia kuatir orang tersebut belum mengenal Tuhan karena hymne datang dari Tuhan. Melihat betapa mulianya lagu-lagu hymne, maka seorang Pemimpin Musik Gereja harus mengerti lagu-lagu hymne. Dia harus dapat mengajar dan menolong jemaat bisa bernyanyi. jangan membuang lagu-lagu hymne yang bernilai tinggi.

\section{Penutup:}

Banyak orang ingin berubah ibadah dengan puji-pijiannya, tetapi tidak tau bagaimana merubahnya. Lebih sedih dirubah oleh orang-orang yang tidak mengerti musik gerejawi. Penulis setuju terjadi perubahan didalam sebuah ibadah termasuk musiknya, tetapi apakah perubahan itu berdampak lebih baik atau lebih buruk? Mengapa kita harus berubah? Apakah salah lagunya atau salah kurang pembinaan atau tidak memiliki Pemimpin Musik Gereja yang handal?Banyak gereja tidak mau bernyanyi lagu-lagu hymne bukan karena hymne itu kuno atau jelek, tetapi tidak ada yang mengajar dan membina karena tidak memiliki Pemimpin Musik Gereja.

\section{Saran:}

Jangan menganggap lagu hymne adalah kuno atau hanya untuk orang tua. Anak muda harus nyanyi nyanyian baru. Ini adalah pandagan yang salah dan tidak beralasan kuat. Apalagi bapa Gereja Methodist ( John Wesley ) berkata: Orang percaya harus memiliki 2 buku, yang satu adalah alkitab dan yang lain adalah lagu hymne (Hymne Methodist). Gereja memiliki tugas dan tanggung jawab didalam pertumbuhan kerohanian jemaat, salah satunya melalui puji-pujian yang baik dan benar. Lengkapilah rekan pelayanan kita dengan seorang Pemimpin Musik Gereja.

Penulis menghimbau, Jangan terlamtat! Mari bergabung dengan STTWMI di Fakultas Musik Gerejawi, penulis adalah salah satu dosen disana. Kami memiliki fasilitas, sarana dan prasarana bagi siswa-siswi musik gereja. Kami memiliki dosen-dosen dari Singapore, Korea Selatan yang sudah pengalaman dan terdidik. Tuhan Yesus memberkati. 


\section{Daftar Pustaka:}

Jane Stuart Smith. Karunia Musik, Jakarta. 2001.

Quentin J. Schultae, Ibadah Hi-tech. Singapore: Singapore Bible College, 2006.

Ronald Allen, Worship Rediscovering the missing Jewel, USA. 1982.

Wiersbe, Warren Whisper. Real Worship. Nashville: Oliver Nelson, 1986.

Yu Qi Nian, Pelayanan Musik Gereja, Hongkong: Fu Ing Zhen Zhu. 1985.

Zhen Han Long. Ibadah Yang Terindah, Taipei: Rong Kuang. 1976. 